\title{
How does bastnäsite form? Replacement of calcite by rare earth carbonates.
}

\author{
ADRIENN MARIA SZUCS ${ }^{1}$, ALEXANDRA \\ STAVROPOULOU ${ }^{2}$, CLAIRE O'DONNELL ${ }^{2}$, SEANA \\ DAVIS $^{2}$ AND JUAN DIEGO RODRIGUEZ-BLANCO ${ }^{2}$ \\ ${ }^{1}$ Trinity College Dublin, the University of Dublin \\ ${ }^{2}$ Trinity College Dublin
}

Presenting Author: szcsa@tcd.ie

The interaction of rare earth bearing ( $\mathrm{La}, \mathrm{Nd}, \mathrm{Dy})$ aqueous solutions with calcite crystals was investigated at ambient and hydrothermal conditions $\left(25-220^{\circ} \mathrm{C}\right)$. This reaction results in the solvent-mediated surface precipitation and subsequent pseudomorphic mineral replacement of calcite by bastnäsite. The crystallization sequence during the replacement reaction is lanthanite $\left[\mathrm{REE}_{2}\left(\mathrm{CO}_{3}\right)_{3} \cdot 8 \mathrm{H}_{2} \mathrm{O}\right] \rightarrow$ kozoite [orthorhombic $\left.\operatorname{REECO}_{3}(\mathrm{OH})\right] \rightarrow$ bastnäsite [hexagonal $\operatorname{REECO}_{3}(\mathrm{OH})$ ], and the ionic radius of the $\mathrm{REE}^{3+}$ and the temperature have a strong influence on the polymorph selection and the crystallization pathways, as well as the kinetics of mineral replacement.

One of the intermediate phases, kozoite, forms an epitaxy by growing oriented onto the calcite surface. This phase forms elongated crystals on [100], with the $\{011\}$ and $\{0 \overline{11}$ as major forms. The epitaxial relationship is (104) $[010]_{\mathrm{cc}} \|(001)[100]_{\mathrm{koz}}$ and is strongly dependent on the ionic radius of the rare earth in the structure of kozoite. The study provides comprehensive information on the potential recrystallization or replacement reactions involving calcite in REE-bearing deposits during hydrothermal and metasomatic processes.

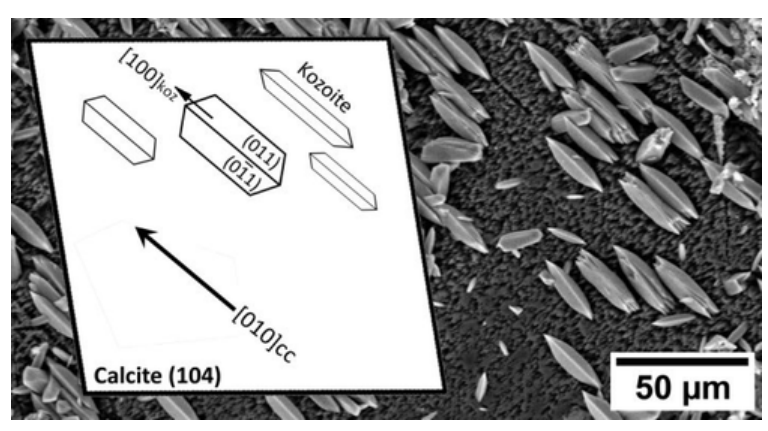

